\title{
Aesthetic Features of Chu Teh-chun's Abstract Painting
}

\author{
Feng Liu \\ School of Fine Arts \\ Jiangsu Normal University \\ Xuzhou, China 221116
}

\begin{abstract}
This article summarizes the important aesthetic features of Chu Teh-chun's abstract paintings, including harmonious beauty, imaginary and actual beauty, rhythmic beauty, natural beauty, and beauty of artistic conception. By analyzing the development and formation of these aesthetic features, this paper studies unique abstract artistic creation concept of Chu Teh-chun with Chinese aesthetic style under the background of western abstraction. The author has made the discussion on the differences between Chinese and Western artistic concepts and Chu Teh-chun's inheritance and development of traditional Chinese art.
\end{abstract}

Keywords-Chu Teh-chun; abstract painting; aesthetic

\section{INTRODUCTION}

Mr. Chu Teh-chun is the first ethnic Chinese academician of the College of the Arts of Institut de France. $\mathrm{He}$ is a world-renowned abstract painter. He graduated from Hangzhou National College of Art in his early years and went to France to pursue artistic ideals in 1955. His abstract paintings are magnificent and bright. These paintings perfectly combine the delicateness of oriental ink paintings with the gorgeousness of Western oil paintings. It integrates the spirit of traditional Chinese painting with the form of western abstract paintings. And it forms an abstract painting style with Chinese artistic conception. For the Chinese audience, his paintings are purely Western modern abstract oil paintings. However, Western audiences generally believe that his works are full of oriental flavor. What are the basic aesthetic features of his abstract paintings? How do audiences of different cultural backgrounds understand and interpret these aesthetic feelings? The author summarizes basic characteristics of the aesthetics of Chu Teh-chun's abstract paintings.

\section{HARMONIOUS BEAUTY - THE PHILOSOPHICAL}

\section{THOUGHT OF HARMONY BETWEEN HEAVEN AND HUMAN}

Most of Chu Teh-chun's mature works have varied shapes, rich colors, and vivid strokes. However, the overall temperament seems to be graceful, peaceful and smooth. This calm and peaceful temperament has remained in Chu Teh-chun's works. Even in its early concrete landscapes, still life and figure paintings, we can feel the same calm and peaceful temperament. This style goes throughout its lifetime. It shows that the painter has a very stable world view. This is the thought of "harmony between heaven and human" of traditional Chinese culture.

Chu Teh-chun was influenced by De Stael and European "non-defining art" in the early stage of abstract painting. However, he once again returned to the Chinese spirit in the process of development. And his works can be distinguished from the abstract paintings of the West. Also, it can be different from the anxiety, pain and resistance of post-war Europeans locked in artistic cages. Xu Fuguan believes that Western expressionism is a kind of fuel-filled catharsis and a reflection of the reality. Chinese art is the calm reflection. Chinese landscape painting is like cool drink in the summer. And it can heal over the cyclothymic of modern people. [1] People can appreciate this beauty from the abstract paintings of Chu Teh-chun.

The Chinese ancients saw the universe as an ever-lasting process of perpetual motion. Humans are an organic part of the universe. The adaption and development is "the harmony between man and nature." Chinese culture emphasizes the "harmony between man and nature". It emphasizes coordination between man and nature. And people can understand the "morality and justice" of the universe. Western culture regards the universe as material entity. And it is the object that human need to understand and conquest. Nature is opposed to people. People can control their destiny only by fighting against it.

The understanding of the universe and life in ancient Chinese philosophy inspired $\mathrm{Chu}$ Teh-chun's deep understanding of life consciousness. And it also achieved beautiful and splendid artistic realm in his works. He transplanted the oriental imagery and spirituality into Western abstraction. The ethereal imagery, color and brushstrokes make us feel the thick energy of life and experience the detached existence of the life ontology. Taiwan commentator Pan Fan makes the comment on Chu Teh-chun. "People are active existence. They should integrate themselves with heaven and earth. Ultimately, heaven and earth will be harmonious. Chu Teh-chun uses life-long artistic exploration to constantly make introspection and innovation, revealing the secrets of life for us in his artistic creation." [2] Fan Di'an believes that Chu Teh-chun's works have realized the "unity of heaven and man" in oriental philosophy on the level of modern culture. It has transformed the life of natural things into an abstract 
art form. And it highlights the inner harmony of spiritual and natural order. This is a re-creation beyond time and space and culture. People can re-recognize the contemporary significance of Chinese traditional culture. [3]

\section{IMAGINARY AND ACTUAL BEAUTY - THE TRANCE}

Chu Teh-chun's abstract works also have an important picture feature. The center area is bright and clear. And the structure is clear. The background area is dark in color. And the structure is illusory. This kind of contrast between the center and the background forms the main form of the picture.

In the 1960s, through the continuous study of ink abstract painting, Chu Teh-chun injected the wet sensation of ink painting into oil paintings. The black hard straight line in the early abstract subject structure began to become virtual, forming a large area of dark vignette surface. Through the virtual structure, Chinese flavor gradually appeared. The author believes that this style of painting is a very crucial step in the transformation of his abstract painting style. It is the internal transformation of the formal language of painting under the influence of two different world views. Chu Teh-chun's early learning of Western abstract art returns to the core value of Chinese traditional aesthetics.

Western world outlook holds that the universe is a complex material structure. They use scientific materialism to analyze and study the intrinsic nature of things, and pay attention to the part and individual control of things. Western art also takes "shape" as the starting point for observing surface structure of the things. In Chinese traditional culture, the universe is made up of chaotic "Qi", which is functional rather than material. The change of all things in the world comes from the flow of "Qi". Jiang Cheng thought that the world view of "Qi" created the Chinese painting with the characteristic of "image". Through the pursuit of spirit, it can get rid of the constraint of physical appearance structure of things. The highest goal of Chinese painting is to make the painting behavior and the universe be mutually related. Chinese painters try to turn virtual space into real life on the picture by vignetting ink paintings and leaving white space. It would grasp the "virtual image" of life flow and discover the internal principle of things. [4] Chu Teh-chun often mentions "cloud and mist" experience in the sketch of Baxian Mountain in Taiwan. He profoundly understands the close relationship between Chinese traditional art and nature.

Chu Teh-chun believes that the source of his creation is a kind of intuitive trance and unconcerned image. It is similar to Laozi's "trance". Through years of unremitting exploration on the canvas, he is finally inspired by the light using method of Rembrandt's works. And he uses light as "Yang" and shadow as "Yin". Between light and shadow, there are complex changes between reality and illusion. It has formed the symbolic painting language. That is to say, it is also the reappearance of the philosophy of "the Book of Changes" that he often says his work should convey. For this connotation of Chu Teh-chun's abstract painting, French art critic Cabanna believes that this is the artist's inner search for the order of the universe. And it is the manifestation of the natural phenomena. [5] Xurigera believes that Chu Teh-chun uses the enthusiasm of others to describe the tension and harmony of the universe. He uses oriental thinking to express the most important connotation of nature. [6]

\section{RHYTHMIC BEAUTY - MUSICALITY IN CALLIGRAPHY}

Carefully observing the abstract modeling in Chu Tehchun's works, it is not difficult to find that the structural relationship has the inherent sense of connection. The large block and small strokes are orderly in the changes. It is like the melody of music, presenting the beautiful rhythm of calligraphy.

For the same abstract painting, Chu Teh-chun's modeling structure is different from Kandinsky's and Mondrian's abstract rational construction. It is different from the action painting of abstract expressionist painters. Pollock and others intend to stimulate mystery and imagination through their own actions in the process of painting. However, the process is spontaneous, random and disorderly. And the picture obviously lacks control and rhythm change. Chu Teh-chun's works are full of the sense of rhythm, which is achieved through long-term calligraphy training with the integration of the eye, hand and heart. The French critic, Hurbert Juin believes that Chu Teh-chun's abstract painting surpasses that of "non-stereotypic" European artist at that time. And he is the foremost abstract painter of the new "Paris School".

Chu Teh-chun believes that listening to the music is the same as seeing a picture. He likes to listen to the western classical music. He often uses the music melody to lead the emotion into the picture scene. Through the synesthesia and agreement between the visual and auditory senses, it would stimulate the picture modeling and color. Influenced by Klee and Kandinsky's theory of painting, he tried to combine western music with Chinese calligraphy. And the musicality in his painting is different from the former two, which has more meanings. After years of hard work, Chu Teh-chun's calligraphy training in Paris has been perfectly applied to the modeling structure of abstract painting. And it becomes formal language with its own strong personality. Critic Gao Tianmin believes that the rhythm of his images would be magnificent, grand and distant. It is a mixture of Western symphonies. Sometimes it is cordial and private. It just likes the melodious Chinese folk music. [7] The painter Wu Guanzhong describes Chu Teh-chun's abstract paintings with the words "noisy of big strings likes rainy, small strings stealing like whispering". [8]

As the core of Chinese national essence and culture, calligraphy plays a pivotal role in Chinese art. Xu Fuguan thought that the "rhyme" of calligraphy was "the spiritual mood surpassing the lines". [1] In Zhu Liangzhi's opinion, as the highest form of Chinese art, the basic spirit of calligraphy lies in "music", which is the dance of lines on paper with musical rhythm. [9] The "rhythm" of calligraphy 
refers to the lines that have been purified by calligraphers. As an independent constituent of the picture, it forms musical rhythm through its own complex, varied and patchy forms. It is known as visual music by traditional Chinese aesthetics. It is a very high state of the modeling art.

According to the comment of Taiwan commentator Wang Zhexiong, Western painters such as Matisse and Kandinsky tried to express musical rhythms with the color. However, Chu Teh-chun has achieved greater breakthroughs in artistic practice and performance. The works show a sense of rhythm through the contrast of color. Also, he can create the modal rhythm of the picture by grasping the dynamics of brush strokes. This is the beauty of the rhythm of strokes that he learned by drawing on the law of of calligraphy. [10]

\section{Natural Beauty - THE Way to ObSERVE CHINESE Classics \& CULTURE}

Western abstract paintings deliberately negate the imitation of objects from the time they were created. Eventually, they obtain no-image picture. And even, they reject the viewer's imagination of objects. Chu Teh-chun has his own views on this. He thinks that abstraction and figuration needn't to be completely opposed. And abstract painting does not necessarily completely exclude images. When the Western abstract falls into a monotonous symbol system, goes toward self-replication and exhausted inspiration, he can continuously obtain rich creative inspiration from the profound communication with nature.

Chu Teh-chun has always insisted that the perceptual source of painting should come from the personal experience of nature. He said: "I have been inspired by the nature. I would make the lyrical and poetic expression. Creation is purely spontaneity. As the Taoists said, 'spit in the chest and breathe...' When creating the paintings, they are all my experience. Some of the paintings were impulses that I couldn't suppress at the time. Some of them were long-lived. Some memories that I think I have forgotten, they would be awakened by the canvas." [11]

"Sketching from nature" is an entity that observes life in Western paintings. In Chinese classical painting theory, the paintings would "write" the "life" of things and the nature. Zhang Xiaoling thinks that this is the fundamental difference between Chinese and Western art observation and expression methods. He believes that the core concept of Western art is to reproduce the authenticity of objects and to express the purely ideal world in individual life consciousness. The observation is "retina imaging" and its spatial structure is static and fixed. China's "mental imagery" is anti-reproduction and non-imitation. The goal is to integrate the individual's life experience with the universe. The screen space has no perspective. Therefore, the "mental imagery" is more able to integrate into the imagination and creativity of the creative subject and to exert intuitive experience and feelings. He believes that this is the ultimate value of Chinese art. [12] The author also believes that this is the fundamental difference between Chu Teh-chun's painting style and western abstraction.
Cabanna noticed that Chu Teh-chun had never sketched in the open air. He was immersed in the studio for several months or several years. Also, he placed himself in the landscape of the canvas. When he was convinced that it was possible to integrate vision and knowledge, he can express overall feelings through images. When merging with the "soleness" of that quest, the landscape was born in the imagination. Cabana believes that $\mathrm{Chu}$ Teh-chun has absorbed and integrated the best traditions of Chinese and Western aesthetics. Through the common teachings of the Song Dynasty painter and the father of western modern art Cézanne, he intercepted an excellent soil containing the wonders of the universe. With the spiritual integration of nature and and meditaton inside, it profoundly comprehends the true meaning of the color of things and the illumination of light. And then, it would create a more realistic picture than reality. The artist finds new forms between what he has seen and the shock he has received. No one has yet reached this state. [13]

Shui Tianzhong believes that Chu Teh-chun is not limited to imitating Western abstractions but surpassing the boundaries among China and the West, abstraction and figuration. There are not purely abstract structures in his works. In the face of nature, the painters would have deep spiritual touching. It is abstract "landscapes" in a broad sense. It does not reproduce the scene of specific reality, but reveals the nature of the painter's deep soul. It shows the long-lasting life flow of nature. Its new life and death, ecstasy and great sadness, blood flow and heartbeat would shock the public. [14]

\section{BEAUTY OF ARTISTIC CONCEPTION — THE POETIC REALM OF "IMAGES BEYOND IMAGES"}

Chu Teh-chun often names his works with Chinese poetry. For example, "Sunshine after Rain", "Through the Mist", "An Hour before Sunrise", "The Echo of the Deep", and "The Snow" help us to interpret the connotation of abstract artwork. People can also often experience some intriguing thoughts, lingering feelings and long aftertaste in Chu Teh-chun's works. This comes from the enlightenment of Chinese ancient poetry.

Taiwan's historian Li Lincan commented on Chu Tehchun's works: "His works are beyond the image of the performer, and are emptied by people. The more abstract and the more spiritual his works are, the more extensive the abstract coverage is. Art was close to the Taoism. And the artists finally have the philosopher's concept and thinking." [15] "Beyond the imagery" is the ancient Chinese literary theory. It comes from "Grades of Poetry" of Si Kongtu. It can also be used as an extremely high standard for evaluating modern abstract painting. In literary and artistic creation, it can be understood as the relationship between the substantivity and indirectness of the image. Through certain artistic image, it triggers broad and far-reaching artistic associations and illusions, transcends the appearance of things, and goes deep into the essence of things.

In 1970, Chu Teh-chun went to the Netherlands to visit the Rembrandt Memorial Exhibition, which triggered deep 
thinking. He found that there were many schools of Western modern paintings. However, it is very rough in production. And their picture quality is low. The lack of connotation only stays on the surface. If artistic works want to be circulated for a long time, they must have profound artistic connotations and high-quality picture effects. If we want to get out of our abstract painting road, we must integrate the profound cultural traditions of our motherland into the western "Kantinsky's abstraction". [16]

How to make my own work be more profound and informative? He resumed his reading of the poems of "Full Collection of Tang Poems" and "Whole Poetry of Song Dynasty" familiar to his childhood since he was a child. And he broadened the inspiration from paintings of ancient Chinese poetry. The poetry in Tang and Song dynasties are like colorful paintings. It would give him a wonderful space for virtual travel. And it integrates the observation, hearings and feelings in nature. His life experiences and cultural cultivation have all sublimated to a new artistic realm. The Chinese "imagery" in his works is full of profound emotions from nature. It transcends the purely abstract conceptual form of the West and reaches the aesthetic realm of "images beyond images" advocated by traditional Chinese art. Thus, it would surpass Western abstraction in the same age.

Chinese ancient poetry emphasizes the implicit beauty of artistic space. After a poem has been created, the poet's emotions are preserved in the unique space of poetry, which is swept up, raised and rippling. Even if the poetry has been read, the lingering aftertaste would still be in the reader's heart for a long time. It is memorable. This is why people often say that poetry has the aesthetic qualities of "romantic charm", "intelligence" and "exhaustion". Chu Teh-chun also often said that the true meaning of poetry is ostensibly invisible and requires careful chewing. People need to calm down and scrutinize good abstract paintings. Through the associative function of imagery, it is possible to realize the profound expression of the artist's inner spirit. [17]

The British art historian Sullivan reads many "offimage" meanings from Chu Teh-chun's abstract paintings. Among them, there are lives that emanate through the light. The shapes those are either hidden or appearing like clouds and waves. And lifelike brushstrokes are as the melody of the tumultuous chaos in the universe. The viewer is sent back to the physical world from the immaterial and transience to eternity. From the perspective of Westerners, he vividly described $\mathrm{Chu}$ Teh-chun's Chinese artistic conception of "images beyond images". [18]

\section{CONCLUSION}

By sorting out the aesthetic characteristics of Chu Tehchun's abstract paintings, we can see that he has made many efforts in integrating Chinese and Western paintings and finding his own artistic style. When the author visited Paris in 2005, the author had a special visit to Mr. Chu Teh-chun. During the conversation, he repeatedly told the importance of the Chinese traditional culture. People must cherish the artistic tradition of the country and inherit the precious legacy left by his ancestors. When Mr. Chu Teh-chun arrived in France, it was the time when abstract painting was surging in the Western art world. He resolutely gave up the realistic style that had persisted for many years and devoted himself to the grand artistic trend. With the continued deepening of artistic creation, he gradually realized the ills of Western abstract painting. He turned to use his mother culture - Chinese traditional culture. The aesthetics of Chinese ancient thought and arts deeply influenced him and freed him from the conceptualization of Western abstract art The gradual ebb and flow of abstractionism in the 1970s illustrates his artistic foresight. Since then, his creations have been really developed and matured. He has gradually gained recognition in the international art world and obtained the academician of College of Fine Arts of Institut de France in 1999.

Art trend is an unavoidable issue for every artist. Chu Teh-chun has always had a clear understanding of this. He believes that painters must have a sincere creative attitude. They must move the public with sincerity. And the work can be finally recognized by the audience. No matter how the painting school renovates style or changes its slogan, if the work does not have the "sincerity", it will not be able to move the audience. And it will be quickly eliminated and forgotten by history until it finally disappears. [19] The author has the same feelings. As an individual of artistic creation, Mr. Chu Teh-chun was able to overcome the contradictions between Chinese and Western cultures with highly responsible attitude towards nurturing his own growth culture and the true feelings of art and the unremitting pursuit of the essence of art. And he overcomes various difficulties in artistic exploration. Eventually, he created abstract art that integrates Chinese and Western aesthetics and unique features.

\section{REFERENCES}

[1] Xu Fuguan. The Spirit of Art in Central Plains [M] Liuzhou: Guangxi Normal University Press, 2007:5,50. 徐复观.中园艺术精神 [M]柳州: 广西师范大学出版社,2007:5,50.

[2] Pan Fan. Thickness, Splendidness and Chu Teh-chun [M]. Taiwan: Artist Press, 2011: 149. 潘幡.浑厚・灿烂・朱德群[M]. 台湾:艺术家 出版社, 2011:149.

[3] Fan Di'an. Address [M]//Chu Teh-chun Retrospective. Beijing: China National Museum of Art, 2010: 21. 范迪安.致辞[M]//朱德群回顾展. 北京:中国美术馆,2010:21

[4] Jiang Chengqing. Spiritual System of Chinese Painting [M]. Lanzhou: Gansu People's Fine Arts Publishing House, 2008; 137 . 姜澄清.中 国绘画精神体系[M].兰州:甘肃人民美术出版社,2008;137.

[5] [France] Pierre Cabanna. Chu Teh-chun [M] Beijing: Sanlian Bookstore, 2000:19, 19. 皮埃尔・卡巴纳. 朱德群 $[\mathrm{M}]$ 北京:三联书 店, 2000:19,19.

[6] Zhu Qing. Chu Teh-chun — From the Son of Han Nationality to French Academician [M]. Zhengzhou: Henan Literature and Art Publishing House, 2007: 168 朱晴.朱德群一从汉家之子到法兰西 院士[M]. 郑州: 河南文艺出版社, 2007:168

[7] Gao Tianmin. Chinese Wisdom and Western Eyes[M]//Chu Teh-chun Shanghai: Shanghai Art Publishing House, 2005:26. 高天民.中国的 智慧西方的眼睛[M]//朱德群.上海:上海画店出版社,2005:26.

[8] Gong An. Forgetting the human and things - Study on Chu Tehchun's Art [J]. Big Stage: 2011.01.118. 龚安.物我两忘一朱德群艺 术探析[J].大舞台:2011.01.118. 
[9] Zhu Liangzhi. The Spirit of Life in Chinese Art [M]. Hefei: Anhui Education Press, 2003: 197. 朱良志.中国艺术的生命精神[M].合肥: 安徽教育出版社,2003:197.

[10] Wang Zhexiong. Light, Image and Rhythm[M]// Chu Teh-chun Retrospective Exhibition in 1988. Taipei: National Museum of Art, 2008:25. 王哲雄.光线、形象和韵律 $[\mathrm{M}] / /$ 朱德群 88 回顾展.台北: 国立艺术博物馆,2008:25.

[11] $\mathrm{Zu}$ Wei. Chu Teh-chun [M]. Shanghai: Wenhui Publishing House, 200:147. 祖蔚.朱德群传[M].上海: 文汇出版社,200:147.

[12] Zhang Xiaoling. Sticking to the Ultimate Values of Chinese Fine Arts [J]. Fine Arts Observation: 2010.03.20. 张晓凌. 坚守中国美术的终 极价值观 $[\mathrm{J}]$ 美术观察:2010.03.20.

[13] [France] Pierre Cabanna. Chu Teh-chun's Paintings: Express Nature, and Praise Nature $[\mathrm{M}] / /$ Chu Teh-chun Exhibition. Guangzhou: Guangdong Museum of Art, 2000:13. [法]皮耶・卡班.朱德群的 画: 抒发心性, 赞美自然 [ M ]//朱德群画展.广州:广东美术 馆, 2000:13.

[14] Shui Zhongtian. Chu Teh-chun and His Paintings [J].Literary Studies:2000.05.113. 水天中. 朱德群和他的画 [J]. 文艺研 究:2000.05.113.

[15] Li Lincan. Beyond the Image of the Performer, and Be Emptied by People $[\mathrm{M}] / /$ Chu Ge. Chu Teh-chun Theory - Chu Teh-chun's Painting Research Report. Taichung: National Taiwan Museum of Fine Arts, 2004:94. 李霖灿. 超以象外, 得其环中 [M]//楚戈. 朱德群 论一朱德群绘画艺术之研究报告.台中:国立台湾美术馆,2004:94.

[16] [France] Dai Haoshi. Several Key Points in Understanding Works[M]// Retrospective Exhibition of Chu Teh-chun's Works in 1988. Taipei: National Museum of Art, 2008:38. [法]戴浩石.几个理 解作品的要诀 $[\mathrm{M}] / /$ 朱德群 88 回顾展. 台北:国立艺术博物馆, 2008:38.

[17] Li Lincan. Beyond the Image of the Performer, and Be Emptied by People $[\mathrm{M}] / / \mathrm{Chu}$ Ge. Chu Teh-chun Theory - Chu Teh-chun's Painting Research Report. Taichung: National Taiwan Museum of Fine Arts, 2004:94. 李霖灿. 超以象外, 得其环中 [M]//楚戈. 朱德群 论一朱德群绘画艺术之研究报告.台中:国立台湾美术馆,2004:94.

[18] [British] Mike Sullivan. Chu Teh-chun's Art [M]// Chu Ge. Chu Tehchun Theory - Chu Teh-chun's Painting Research Report. Taichung: National Taiwan Museum of Art, 2004: 116. [英]麦克・苏利文. 朱德 群的艺术 $[\mathrm{M}] / /$ 楚戈. 朱德群论一一朱德群绘画艺术之研究报告. 台 中:国立台湾美术馆,2004:116.

[19] [France] Chu Teh-chun. My Painting Process [J]. Literary and Art Research: 2000, 9: 102-106. [法]朱德群. 我的绘画历程[J]. 文艺研 究:2000,9:102-106. 